\title{
Screening for mutations in exon 4 of the LDL receptor gene: identification of a new deletion mutation
}

Leonora Theart, Maritha J Kotze, Elzet Langenhoven, Odell Loubser, Armand V Peeters, Caroline J Lintott, Russell S Scott

\begin{abstract}
DNA from 14 unrelated New Zealand familial hypercholesterolaemia (FH) heterozygotes, originating from the United Kingdom, was screened for mutations in exon 4 of the low density lipoprotein receptor (LDLR) gene. One patient was heterozygous for mutation D206E, which was initially identified in South Africa. The chromosomal background of this mutant allele was compatible with that described previously in Afrikaner and English patients, suggesting that this mutation originated in the United Kingdom. The $\mathbf{2}$ bp deletion in codon 206 and mutations D154N and D200G, previously reported in English FH patients, were not detected in this sample. In one of the patients, however, a new deletion of 7 bp was identified after nucleotide 581 (or 582) in exon 4 of the LDLR gene.
\end{abstract}

(F Med Genet 1995;32:379-382)

Familial hypercholesterolaemia $(\mathrm{FH})$ is caused by mutations in the low density lipoprotein receptor (LDLR) gene. ${ }^{1}$ Variation in the clinical expression of heterozygous $\mathrm{FH}$ often complicates the diagnosis of this autosomal dominant disease, which is characterised by raised LDL cholesterol levels and the presence of tendon xanthomata and coronary heart disease (CHD). Although accurate diagnosis of $\mathrm{FH}$ is possible by means of molecular methods, their use in heterogeneous populations is limited at present owing to mutational heterogeneity of the LDLR gene. In some parts of the world, however, where specific FH related mutations occur in a large proportion of patients, owing to "founder effects" resulting from migration and cultural or geographical isolation, ${ }^{2-6}$ cost effective DNA diagnosis of FH can be applied. We have previously reported on the value of a molecular diagnostic service for FH in Afrikaners ${ }^{7}$ where three founder related LDLR gene mutations are responsible for $\mathrm{FH}$ in up to $90 \%$ of cases. ${ }^{5}$ Screening for these mutations in other populations has shown that the D154N and D206E mutations in exon 4 of the LDLR gene are likely to be of English origin, while the V408M mutation in exon 9 of the gene originated in the Netherlands. ${ }^{89}$

In this study we investigated the possibility that specific LDLR gene mutations were introduced from the United Kingdom to New Zealand, thereby facilitating diagnosis of $\mathrm{FH}$ at the genomic level. We screened polymerase chain reaction (PCR) amplified ${ }^{10}$ genomic DNA from 14 unrelated subjects with hypercholesterolaemia originating from the United Kingdom for mutations in exon 4 of the LDLR gene. This gene region appears to be particularly mutation prone and was found to be mutated in about $8 \%$ of $\mathrm{FH}$ patients in the United Kingdom. ${ }^{811}$

\section{Materials and methods}

PATIENTS

The patient sample consisted of 14 apparently unrelated hypercholesterolaemic subjects (nine males, five females) attending the Lipid Disorders Clinic at the Christchurch Hospital in New Zealand (table). These study participants, originating from the United Kingdom, were diagnosed as $\mathrm{FH}$ heterozygotes based on the presence of tendon xanthomata and a positive family history of hypercholesterolaemia consistent with autosomal dominant inheritance. All patients had received previous extensive dietary counselling, and were stabilised on diets containing $<30 \%$ of total energy as fat. All patients were previously using hypolipidaemic drug therapy, which was withdrawn six weeks before baseline blood tests. All patients had normal renal, hepatic, and thyroid function. Blood samples for measurement of lipids were obtained after a 12 hour fast following six weeks on diet alone.

\section{PLASMA LIPID AND LIPOPROTEIN}

DETERMINATIONS

Levels of total plasma cholesterol (TC), total triglycerides (TG), and HDL cholesterol (HDLC) were determined in the Hunter-Nye Lipid Laboratory in Dunedin (NZ). TC and TG were measured in plasma and plasma fractions using enzymatic kits (Boehringer Mannheim) and controls from the Australian Lipid Standardisation programme. HDLC was measured in the supernatant obtained after precipitation of lipoproteins containing apolipoprotein B from plasma. Plasma LDL cholesterol (LDLC) was calculated by the Friedewald equation (LDLC $=\mathrm{TC}-$ (HDLC + TG/2・18).

LOW DENSITY LIPOPROTEIN RECEPTOR FUNCTION

LDLR function was assessed using the method of Cuthbert et al. ${ }^{12}$ Peripheral blood lym- 
Clinical and demographic characteristics of 14 study participants

\begin{tabular}{|c|c|c|c|c|c|c|c|c|}
\hline \multirow[t]{2}{*}{ Patient } & \multirow[t]{2}{*}{ Sex } & \multirow[t]{2}{*}{ Age (y) } & $T C$ & $T G$ & $H D L C$ & $L D L C$ & \multirow[t]{2}{*}{$X M T A$} & \multirow[t]{2}{*}{$C H D$} \\
\hline & & & \multicolumn{4}{|c|}{$(\mathrm{mmol} / \mathrm{l})$} & & \\
\hline FH1 & $\mathrm{F}$ & 69 & $9 \cdot 8$ & 1.0 & $1 \cdot 8$ & $7 \cdot 4$ & + & + \\
\hline $\mathrm{FH} 2$ & $\mathrm{~F}$ & 43 & 8.5 & 0.9 & $1 \cdot 2$ & 6.9 & + & - \\
\hline $\mathrm{FH} 3$ & M & 31 & 8.9 & $1 \cdot 4$ & 1.3 & $6 \cdot 9$ & + & - \\
\hline FH4 & M & 55 & $7 \cdot 1$ & 1.0 & 1.0 & $5 \cdot 6$ & + & - \\
\hline FH5 & $\mathbf{M}$ & 67 & $7 \cdot 4$ & $2 \cdot 0$ & 0.9 & 5.5 & + & + \\
\hline FH6* & $\mathrm{F}$ & 62 & $10 \cdot 3$ & 1.4 & $1 \cdot 0$ & $8 \cdot 6$ & + & - \\
\hline FH7 & $\mathrm{F}$ & 46 & $7 \cdot 4$ & 0.8 & $1 \cdot 2$ & 5.9 & + & - \\
\hline FH8* & M & 44 & 12.9 & $1 \cdot 7$ & 1.2 & 10.9 & + & + \\
\hline FH9 & $M$ & 70 & $10 \cdot 1$ & $1 \cdot 2$ & $1 \cdot 4$ & $8 \cdot 2$ & + & - \\
\hline FH10 & $M$ & 43 & $9 \cdot 8$ & $1 \cdot 1$ & 1.2 & $8 \cdot 1$ & + & - \\
\hline FH11 & F & 22 & $8 \cdot 7$ & 1.6 & 1.8 & $6 \cdot 2$ & + & - \\
\hline $\mathrm{FH} 12$ & $M$ & 41 & 9.9 & 1.8 & 1.2 & 7.9 & + & - \\
\hline $\mathrm{FH} 13$ & M & 35 & $7 \cdot 3$ & $1 \cdot 1$ & 1.4 & $5 \cdot 4$ & + & - \\
\hline $\mathrm{FH} 14$ & $\mathbf{M}$ & 38 & 11.6 & 1.8 & $1 \cdot 1$ & $9 \cdot 6$ & + & + \\
\hline
\end{tabular}

* Molecularly characterised FH heterozygotes.

Diet treated lipid levels are given for total cholesterol (TC), triglycerides (TG), high density lipoprotein cholesterol (HDLC), and low density lipoprotein cholesterol (LDLC)

$\mathrm{XMTA}$, tendon xanthomas; CHD, coronary heart disease.

phocytes were isolated from $10 \mathrm{ml}$ of EDTA anticoagulated blood. In each well $5 \times 10^{3}$ cells were cultured in RPMI 1640 medium supplemented with $1 \%$ lipoprotein poor plasma and $0.5 \mu \mathrm{g} / \mathrm{ml}$ of phytohaemagglutinin. Mevinolin $(0.5 \mu \mathrm{mol} / \mathrm{l})$ was included in all cultures except for control wells which contained DMSO. Human LDL isolated from normocholesterolaemic subjects was added at concentrations between 0 and $5 \mu \mathrm{g} / 1$ to triplicate wells. Each control culture was treated identically and with similar concentrations of LDL. After 96 hours incubation, $1 \mu \mathrm{Ci}\left[\mathrm{H}^{3}\right]$-thymidine was added and a further 18 hour incubation was carried out. Cells were then harvested and $\left[\mathrm{H}^{3}\right]$-thymidine incorporation into DNA was measured by scintillation counting for one minute.

The percentage of mevinolin inhibition was calculated and data were plotted using the sigma Plot computer program. The assay design allowed the measurement of receptor function from lymphocytes isolated from a maximum of three different hyperlipidaemic subjects together with an internal control provided by a healthy normocholesterolaemic subject. Patients with normal LDLR function (four of the initial 18 study participants) were excluded from this study and were screened for mutations in the apolipoprotein (apo) B-100 gene $^{1314}$ causing familial defective apolipoprotein B-100 (FDB).

\section{ANALYSIS OF GENOMIC DNA}

Genomic DNA was extracted from peripheral blood samples and exon 4 of the LDLR gene amplified by the PCR method ${ }^{10}$ using two pairs of oligonucleotide primers ${ }^{51516}$ :

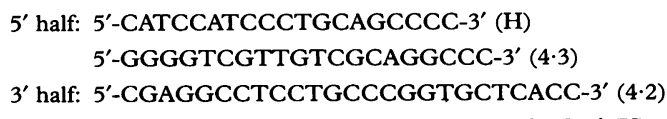

PCR conditions were according to Kotze et $a l,{ }^{5}$ except that the $5^{\prime}$ half of exon 4 was amplified at an annealing temperature of $63^{\circ} \mathrm{C}$.

Aliquots of amplified $3^{\prime}$ exon 4 DNA of the LDLR gene were digested with DdeI, MboII, or $M s p \mathrm{I}$, in order to screen for the D206E,
D154N, or D200G mutations respectively. ${ }^{511}$ Samples were electrophoresed for two hours at $100 \mathrm{~V}$ on $3 \%$ Metaphor gels (FMC Bioproducts), stained with ethidium bromide, and photographed under ultraviolet light.

Directly after PCR amplification, $5 \mu \mathrm{l}$ aliquots of the $5^{\prime}$ half and $3^{\prime}$ half exon 4 LDLR gene products from subjects normal for the three above mentioned mutations were mixed with an equal volume of gel loading buffer (95\% formamide, $20 \mathrm{mmol} / 1 \mathrm{EDTA}, 0.05 \%$ bromophenol blue, $0.05 \%$ xylene cyanol) and electrophoresed on a $30 \mathrm{~cm}$ vertical and $1 \mathrm{~mm}$ thick low cross linking $(1 \% \mathrm{C}) 10 \%$ polyacrylamide gel supplemented with $15 \%$ urea. ${ }^{17}$ Electrophoresis was performed in $0.6 \mathrm{TBE}$ at room temperature $\left(<30^{\circ} \mathrm{C}\right)$ at $800 \mathrm{~V}$ for five to six hours. The gel was stained in a solution of $0.6 \times \mathrm{TBE}$ containing $1 \mu \mathrm{g} \mathrm{ml}^{-1}$ ethidium bromide.

After detection of altered heteroduplex bands characteristic of a small deletion in the $3^{\prime}$ half of exon 4 in one subject, the remaining PCR product was electrophoresed overnight on a standard $5 \%$ polyacrylamide gel at $150 \mathrm{~V}$ to obtain adequate separation of the normal and mutant alleles. The faster migrating mutant allele (homoduplex) was excised from the gel and eluted overnight in TE $(10 \mathrm{mmol} / 1$ Tris$\mathrm{Cl}, 1 \mathrm{mmol} / 1$ EDTA (pH 8.0). Before reamplification of an aliquot of the eluate with the set of $3^{\prime}$ half primers (see above), primer 4.2 was phosphorylated at its $5^{\prime}$ end. Single stranded templates were prepared by using a PCR preparation kit according to the manufacturer's (Pharmacia Biotechnology, Uppsala, Sweden) instructions and sequenced with T7 DNA polymerase (T7 sequencing kit, Pharmacia Biotechnology).

Haplotype analyses were performed using four intragenic LDLR gene polymorphisms: the SmaI restriction fragment length polymorphism (RFLP) in intron $7,{ }^{18}$ the StuI RFLP in exon $8,{ }^{19}$ the AvaII RFLP in exon $13,{ }^{20}$ and the NcoI RFLP in exon $18 .^{21}$ Genotypes at the polymorphic sites were determined by restriction enzyme digestion of PCR amplified DNA and gel electrophoresis. FH associated haplotypes were deduced by homozygosity for the polymorphisms analysed. 


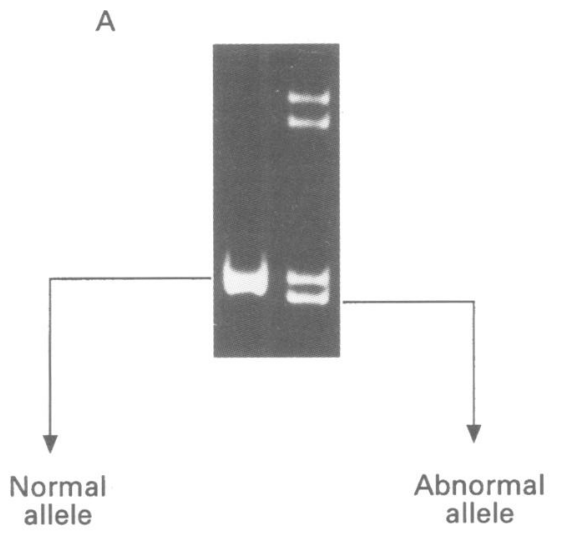

B

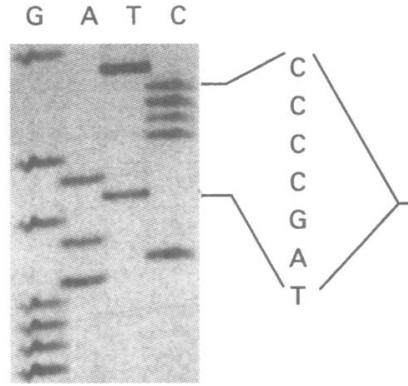

G $\quad A \quad T \quad C$

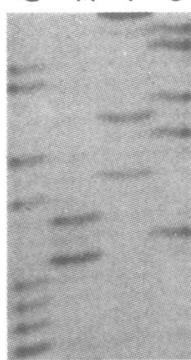

Detarection and characterisation of the mutation in exon 4 of the LDLR gene. (A) Heteroduplex analysis in a polyacrylamide gel. (B) Allele specific sequencing. Left, sequence of a normal control; right, sequence of the abnormal allele of patient FH8.

\section{Results}

The clinical and demographic characteristics of the study population are summarised in the table. All 14 patients showed reduced receptor function consistent with heterozygous FH. Analysis of band patterns of PCR amplified exon 4 DNA of the patients after digestion with DdeI, MboII, or MspI showed that FH6 was heterozygous for the D206E mutation. Genotyping at four polymorphic sites showed that this patient was homozygous for the SmaI $(++)$, StuI $(++)$ and, AvaII $(--)$ RFLPs, and heterozygous for the NcoI (+-) RFLP. The chromosomal background of the base change at nucleotide 681 was thus compatible with the originally described mutant allele.

Heteroduplex analysis of PCR products amplified from the $5^{\prime}$ half $(215 \mathrm{bp})$ and $3^{\prime}$ half $(330 \mathrm{bp})$ of exon 4 did not show altered mobility bands characteristic of previously described mutations. In FH8, however, analysis of the $330 \mathrm{bp}$ fragment showed two slower migrating heteroduplex bands and one faster migrating homoduplex band (figure). Direct DNA sequence analysis of the faster migrating mutant allele of this patient showed a $7 \mathrm{bp}$ deletion (TAGCCCC or AGCCCCT) between nucleotides 581 (or 582) and 589 (or 590) (figure). This deletion causes a frameshift mutation, whereby a truncated protein of the first 173 residues of the LDLR with an additional eight abnormal residues (Ala-Arg-ProSer-Ser-Ser-Thr-Ala) and a premature stop codon (codon 182) would be created. FH8 was homozygous for all four RFLPs analysed, indicating that the $7 \mathrm{bp}$ deletion is associated with haplotype $S m a \mathrm{I}-/ S t u \mathrm{I}+/ A v a \mathrm{II}+/ N c o \mathrm{I}+$ of the LDLR gene.

\section{Discussion}

We screened 14 New Zealand patients presenting with primary hypercholesterolaemia and clinical signs of cholesterol deposition for mutations in exon 4 of the LDLR gene. Mutations in this region of the gene were found to underly $\mathrm{FH}$ in about $8 \%$ of patients in the United Kingdom, ${ }^{811}$ from where the study population originated. Furthermore, more than $20 \%$ of the point mutations and small rearrangements reported to date reside in exon $4,{ }^{22}$ including the first molecularly characterised de novo mutation. ${ }^{23}$

In our study population one patient was heterozygous for the previously described D206E mutation, and her genotype was consistent with the mutation being carried on the same haplotype as was reported originally in a South African FH homozygote. ${ }^{1524}$ This mutation, occurring in the majority of affected Afrikaners $(\sim 60 \%),{ }^{5}$ gives rise to a relatively mild form of $\mathrm{FH}^{25}$ Subsequent detection of this mutation in FH patients of English ancestry in the United Kingdom, ${ }^{8}$ the Netherlands, ${ }^{9}$ North America, ${ }^{22}$ and now also in New Zealand, indicates that the mutation originated in the United Kingdom. This view is further supported by the haplotype analyses that were conducted in the respective studies.

The new mutation identified in exon 4 involves a $7 \mathrm{bp}$ deletion after nucleotide 581 (or 582) in the LDLR gene. This mutation has not been observed in 500 normal chromosomes screened by heteroduplex analysis (data not shown), and is consistent with the FH phenotype and reduced receptor function observed in FH8. If the RNA is spliced normally, the deletion can be expected to lead to a frameshift and stop codon, and the resulting truncated protein is likely to be rapidly degraded in the cell. Further evidence for the dysfunctional nature of the deletion mutation is the fact that it occurred in the highly conserved apolipoprotein (apo) E/apo B binding repeat 5 of the LDLR. ${ }^{26}$ Repeat 5 is unique among the seven ligand binding repeats in that its structural integrity is required for binding of both the receptor's ligands. Binding of apo B-100 of LDL requires the integrity of repeats 2 to 7 , whereas binding of apo $E$ of $\beta-V L D L$ is determined predominantly by repeat $5 .^{27}$

In summary, two of the $14 \mathrm{FH}$ patients analysed in this study were heterozygous for mutations in exon 4 of the LDLR gene, and haplotype data indicated that mutation D206E was introduced from the United Kingdom to New Zealand. Of the initial study population of 18 lipid clinic patients, three clinically affected cases exhibiting normal LDLR activity were heterozygous for the apo $B_{3500}$ mutation causing FDB ( $\mathrm{H} \mathrm{Lu}$ et al, submitted). These resulted in a total of $5 / 18(28 \%)$ patients having the molecular basis of their hypercholesterolaemia determined. Owing to the small numbers analysed, we cannot deduce whether the mutations in the study population are representative of 
those that will be found in other $\mathrm{FH}$ patients in New Zealand. Future screening for the new $7 \mathrm{bp}$ deletion identified in this study, as well as the point mutations detected in the LDLR and apo B genes, will allow frequency determination of the respective mutations. Furthermore, DNA screening of additional family members for known mutations will be of particular importance in children and young adults without tendon xanthomas, where prevention of symptomatic $\mathrm{FH}$ can be achieved by lowering of CHD risk factors early in life. Such screening can be performed cost effectively by heteroduplex analysis in low cross linked polyacrylamide gels. ${ }^{1728}$

We wish to acknowledge J Brusnicky for critical reading of the manuscript. This work was supported by the South African Medical Research Council, the Cape Provincial Administration, and the University of Stellenbosch.

1 Goldstein JL, Brown MS. Familial hypercholesterolemia. In: Scriver CR, Beaudet AL, Sly WS, Valle D, eds. The In: Scriver CR, Beaudet AL, Sly WS, Valle D, eds. The
metabolic basis of inherited disease. 6th ed. New York: metabolic basis of inherited diseas

2 Hobbs HH, Brown MS, Russell DW, Davignon J, Goldstein JL. Deletion in the gene for the low-density lipoprotein receptor in a majority of French Canadians with familia hypercholesterolemia. $N$ Engl f Med 1987;317:734-7.

3 Lehrman MA, Schneider WJ, Brown MS, et al. The Leb anese allele at the LDL receptor gene locus: nonsens mutation produces truncated receptor that is retained in
the endoplasmic reticulum. $\mathcal{F}$ Biol Chem $1987 ; 262: 401-10$.

4 Aalto-Setälä K, Helve E, Kovanen PT, Kontula K. Finnish type of low density lipoprotein receptor gene mutation (FH-Helsinki) deletes exons encoding the carboxyl-terminal part of the receptor and creates an internalizationdefective phenotype. $\mathcal{F}$ Clin Invest 1989;84:499-505.

5 Kotze MJ, Langenhoven E, Warnich L, du Plessis L, Retie AE. The molecular basis and diagnosis of familial hypercholesterolemia in South African Afrikaners. Ann Hum Genet 1991;55:115-21.

6 Meiner V, Landsberger D, Berkman N, et al. A common Lithuanian mutation causing familial hypercholesterolemia in Ashkenazi Jews. Am f Hum Genet 1991;49:443-9.

7 Kotze MJ, Langenhoven E, Theart L, Marx MP, Oosthuizen CJJ. Report on a molecular diagnostic service for familial 15-21.

8 Gudnason V, King-Underwood L, Seed M, Sun X-M, Soutar AK, Humphries SE. Identification of recurrent Soutar AK, Humphries SE. Identification of recurrent
and novel mutations in exon 4 of the LDL receptor and novel mutations in exon 4 of the LDL receptor gene in patients with familial hypercholesterolemia in

9 Defesche JC, van Diermen DE, Lansberg PJ, et al. South African founder mutations in the low-density lipoprotein receptor gene causing familial hypercholesterolemia in the receptor gene causing familial hypercholesterolem

10 Saiki RK, Gelfand DH, Stoffel S, et al. Primer directed enzymatic amplification of DNA with a thermostable DNA polymerase. Science 1988;239:487-91.

11 Gudnason V. Mak YT, Betridge J, McCarthy SN, Humphries SE. Use of the single-strand conformational polymorphism method to detect recurrent and novel mutations morphism method to detect recurrent and novel mutations with familial hipercholesterolemia: detection of a novel with familial hypercholesterolemia: detection of

12 Cuthert IA East CA, Bilheimer DW, Lipsky PE. Detection of familial hypercholesterolemia by assaying functional of familial hypercholesterolemia by assaying functional low-density-lipoprotein rece

13 Soria LF, Ludwig EH, Clarke HRG, Vega GL, Grundy SM $\mathrm{McCarthy}$ BJA. Association between a specific apolipoprotein B mutation and familial defective apolipoprotein B-100. Proc Natl Acad Sci USA 1989;86: 587-91.

14 Pullinger CR, Hennessy LK, Love JA, et al. Familial liganddefective apolipoprotein $\mathrm{B}$ : identification of a new mutation that decreases LDL receptor binding affinity. Circulation 1993;88:1-322.

15 Kotze MJ, Warnich L, Langenhoven E, Du Plessis L, Retief AE. An exon 4 mutation identified in the majority of South African familial hypercholesterolaemics. $f \mathrm{Med}$ Genet 1990;27:298-302

16 Yamamoto T, Davis CG, Brown MS, et al. The human LDL receptor: a cysteine-rich protein with multiple Alu sequences in its mRNA. Cell 1984;39:27-38.

17 Peeters AV, Kotze MJ. Improved heteroduplex detection of single-base substitutions in PCR-amplified DNA. PCR Methods Applic 1994;4:188-90.

18 Jensen LG, Jensen HK, Kjeldsen $M$, et al. A new, highly informative SmaI polymorphism in intron 7 of the low informative Smal polymorphism in intron 7 of the low 1994;45:52-3.

19 Kotze MJ, Retief AE, Brink PA, Weich HFH. A DNA polymorphism in the human low-density lipoprotein repolymorphism in the human low-density

20 Hobbs HH, Esser V, Russell DW. AvaII polymorphism in the human LDL receptor gene. Nucleic Acids Res 1987; the human

21 Kotze MJ, Langenhoven E, Dietzsch E, Retief AE. RFLP associated with the low-density lipoprotein receptor gene (LDLR). Nucleic Acids Res 1987;15:376.

22 Hobbs HH, Brown MS, Goldstein JL. Molecular genetic of the LDL receptor gene in familial hypercholesterolemia. Hum Mutat 1992;1:445-66.

23 Kotze MJ, Theart L, Peeters A, Langenhoven E. A de novo duplication in the low density lipoprotein receptor gene. Hum Mutat 1994;4.

24 Kotze MJ, Langenhoven E, Retief AE, et al. Haplotypes identified by 10 DNA restriction fragment length polymorphisms at the human low density lipoprotein recepto locus. F Med Genet 1989;26:255-9.

25 Kotze MJ, de Villiers WJS, Steyn K, et al. Phenotypic variation among familial hypercholesterolemics heterozygous for either one of two Afrikaner founder LDL receptor mutations. Arterioscler Thromb 1993;13:1460-8.

26 Mehta KD, Chen WJ, Goldstein JL, Brown MS. The low density lipoprotein receptor in Xenopus laevis. $\mathcal{F}$ Biol Chem 1991;266:10406-14.

27 Russell DW, Brown MS, Goldstein JL. Different combinations of cysteine-rich repeats mediate binding of low density lipoprotein receptor to two different proteins. $\mathcal{f}$ Biol Chem 1989;264:21682-8.

28 Kotze MJ, Langenhoven E, Peeters AV, Theart L, Oosthuizen CJJ. Detection of two point mutations causing thuizen CJJ. Detection of two point mutations causing analysis. Mol Cell Probes 1994;8:513-18. 